\title{
A Case Study of Foreign Direct Investment and Economic Growth Relationship in Turkey
}

\author{
Mehman Karimov \\ Davit Belkania
}

\begin{abstract}
Foreign direct investment is believed to enhance long-term economic growth of a country through knowledge spillovers and technology transfers. This paper is an empirical attempt to check the effects of the foreign direct investment (FDI) on the economic growth (GDP) of Turkey. The paper uses time span from 1980 to 2017 for statistical analysis. Johansen co-integration and Granger causality tests were applied for empirical analysis. The results of the tests confirmed the presence of the co-integration between GDP and FDI as it was expected from the beginning. Furthermore, Granger causality test showed the unidirectional causality from FDI to GDP.
\end{abstract}

Keywords: Turkey, Foreign Direct Investment inflow (FDI), Gross Domestic Product (GDP), knowledge spillovers, technological advances

\section{Introduction}

Foreign Direct Investment (FDI) can be defined as the flow of cash organized by a unit or an individual, which aims at the business located in another country. The essential feature of FDI is the ability to establish an effective control over the decision-making process of a foreign business or substantially have an influence on it at the very least.

The role of foreign direct investment has been on the rise since the second half of the 1980s. The new management understanding and a considerable amount of possibilities are brought together resulting from technological advances, these investments have been demanded by both developing countries and developed countries. Foreign investments which was previously considered as a negative exertion are now put into practice in many countries due to the positive contributions they have made, as a result they are willing to open their borders and pay attention to attracting more direct foreign investment. Turkey has adopted new policies and strategies in this regard as it has been witnessing the initiation of foreign direct investment in the country as well as the widespread view that the problems of the countries suffering from capital shortages will arise immediately and have a positive effect on other macroeconomic indicators. In Turkey, promotion of the FDI through various policies is quite multidimensional. Turkish government utilises intersectoral development approach. The manufacturing, retail, logistics, communications and financial services industries have been the major beneficiaries of FDI in Turkey since 2002 \{Citation\}. As for the legislative part, Turkish government undergone the set of changes to create more flexible investment climate. According to the "Foreign Direct Investment Law" issued in 2003, foreign investors shall be subject to equal treatment with domestic investors; Foreign investors can freely transfer abroad: net profits, dividends, proceeds from the sale or liquidation of all or any part of an investment (Deichmann, Karidis, \& Sayek, 2003).

In addition to the efforts of the Turkish government to create competitive investment environment, geographical location played an important role in success of Turkish economy. It has unique location, lying in both Europe and Asia and serving as a bridge between the two biggest markets. Thus, giving a stimulus to the policy makers to develop outward-oriented growth state.

Besides the practical importance of this article to justify current policy changes in Turkey favouring FDI driven growth, we will enrich the existing literature regarding FDI and economic growth and eliminate the gap between theory and practice.

The article starts with section 2, in which we expound literature review about FDI inflow and Economic Growth. Our model which was applied in this paper and its result based on statistical analysis along with the data set will be illustrated in section 3. In section 4, disclosed conclusion according to achieved results will be made. Finally, section 5 will present all the references used. 


\section{Literature review}

(Alagöz, Erdoğan, \& Topallı, 2008), the relationship between direct foreign investment in Turkey and economic growth has been examined for the period 1992-2007. Resulted no causal relationship between direct foreign capital investments and economic growth from the study. The regression analysis for period 2002-2007 was examined in the study. The elasticity coefficient of the model indicates the effect of foreign direct investment on economic growth is moderate.

(Şen \& Saray, 2010) analysed the effect of direct foreign capital investments on economic growth in Turkey using panel data regression analysis. Positive contributions to economic growth lead to direct foreign capital investments in Turkey.

(Yilmaz, Kaya, \& Akinci, 2011), the effects of foreign direct investment on economic growth have been analysed for the Turkish economy for the 1980-2008 period. In the analysis, two variables were used as gross domestic product and foreign direct investment. Time series analysis method was used in the study. Resulting a one-way causality relation from foreign direct investment to economic growth. It is also seen that the variables are co-integrated. Positive effects on economic growth from foreign direct investments shown from the estimation results.

(Gürsoy \& Kalyoncu, 2012) analysed the impact of direct foreign investment on economic growth between 1977 and 2010 in Georgia. Engle-Granger co-integration test and Granger causality analysis were used in the study. Results show that the two variables are co-integrated, that is, they act together in the long run. Which also gave the conclusion that direct foreign investment is the reason for economic growth.

(Çeştepe, Yildirim, \& Bayar, n.d.), the data for the period 1974-2011 used for the direct causal relationship between foreign direct investment, growth and foreign trade in Turkey. The long-term causality between the variables was investigated by following the Toda-Yamamoto method in the study. Findings obtained; "Growth based export", "export dependent FDI" and "import dependent export" hypothesis. These findings can be interpreted as the fact that the import-based export structure and FDI inflows do not change this, so the export-based growth hypothesis cannot be verified in Turkey.

(Younus, Sohail, \& Azeem, 2014) analyzed the impact of foreign direct investment in Pakistan on economic growth for the period 2000-2010. The two-step least squares method is used in the study. As a result, there is a positive relationship between economic growth and foreign direct investment. Domestic investment, exports and political stability have been found to be very important in the selection of foreign direct capital in Pakistan.

(Muhammad \& lijishar, 2015) analyzed the impact of foreign direct investment on economic growth in Nigeria between 1970 and 2013. Time series analysis method was applied in the study. As a result, a one-way relationship between foreign direct investment and economic growth; there was no relationship between foreign direct investment and unemployment. A positive but statistically insignificant relationship was found between the foreign direct investments and the economic growth in Nigeria in the short and long term.

\section{Data, Methodology and Model Results}

\subsection{Data and Methodology}

The time series data set has been used for applied analyses part of paper, covered the period span from 1980 to 2017. Two variables were utilized in the model: GDP (Gross Domestic Product) and FDI (Foreign Direct Investment inflows) those were obtained from World Bank Group ("World Bank Group - International Development, Poverty, \& Sustainability," n.d.). As software, Gretl and EViews were employed to fulfil empirical part of the paper. The long-run implications of FDI on economic growth of Turkey can be detected through regression analysis. Before applying the regression model, stationery test was performed through the Augmented Dickey-Fuller (ADF) test. Stationery level is the crucial part in the time-series analysis. In fact, running the conventional regression analysis on non-stationary time-series can be consistent if the linear combination of the selected variables results in stationary residuals, otherwise, it leads to the spurious results. In this case, statistical property like co-integration appears to deal with non-stationary time-series and detect the long-run relationship between them. Thus, the Johansen co-integration test was employed for our empirical study. The test examines the multiple linear combinations for more than one variable, that results in a stationary process. The Johansen test uses two statistics to identify the number of co-integration vectors: The trace and the maximum eigenvalue tests. In addition to our empirical examination, we employed the Granger Causality test to check the causality between the observed series. 


\subsection{Model Results}

\subsubsection{Unit root test and order of integration}

As the pre-condition of Johansen co-integration test suggests, selected time-series must be non-stationary, $I(1)$. Therefore, we performed ADF test individually on both variables. The null hypothesis of the ADF test states that there is a unit root in the series. The null hypothesis is rejected if the P-value is less than $5 \%$, thus, accepting the alternative hypothesis of no unit root in the series.

\section{Table 1. ADF test results.}

\begin{tabular}{lll}
\hline $\begin{array}{l}\text { ADF test at Level. } 9 \text { lags, unit-root null hypothesis: } \mathrm{a}=1 \\
\text { model: }(1-\mathrm{L}) \mathrm{y}=\mathrm{b} 0+\mathrm{b} 1^{*} \mathrm{t}+(\mathrm{a}-1)^{*} \mathrm{y}(-1)+\mathrm{e}\end{array}$ & LnGDP & \\
\hline Estimated value of $(\mathrm{a}-1)$ & -0.4412 & -0.4049 \\
Test statistic & -3.0718 & -2.9647 \\
P-value & 0.1278 & 0.1554 \\
\hline ADF test at First Difference. 9 lags, unit-root null hypothesis: $\mathrm{a}=1$ & LnGDP & $\mathrm{LnFDI}$ \\
model: $(1-\mathrm{L}) \mathrm{y}=\mathrm{b} 0+(\mathrm{a}-1)^{*} \mathrm{y}(-1)+\ldots+\mathrm{e}$ & & \\
\hline Estimated value of $(\mathrm{a}-1)$ & -1.6721 & -1.1217 \\
Test statistic & -4.1972 & -7.3377 \\
P-value & 0.0006 & $3.575 \mathrm{e}-07$ \\
\hline
\end{tabular}

Source: Author's own calculation

The results presented above showed that both variables have a unit root at levels, as long as we can't reject the null hypothesis, and become stationary at first difference (See Table 1). Therefore, we can conclude that the observed data are integrated of order one, $I(1)$ and continue to the Johansen co-integration test.

\subsubsection{Johansen co-integration test}

According to the ADF unit root test results, our series are integrated of the same order, I(1). Thus, it allows us to continue with Johansen co-integration procedure. The test uses two statistical measures from Trace and Eigenvalue tests.

\section{Table 2. Johansen co-integration test results}

\begin{tabular}{|c|c|c|c|c|}
\hline \multicolumn{5}{|c|}{$\begin{array}{l}\text { Johansen Co-integration test: Sample (adjusted): } 19 \\
\text { differences): } 1 \text { to } 1 .\end{array}$} \\
\hline \multicolumn{5}{|c|}{ Unrestricted Co-integration Rank Test (Trace) } \\
\hline Hypothesized No. of CE(s) & Eigenvalue & Trace Statistic & 0.05 Critical Value & Prob. \\
\hline None & 0.3522 & 16.559 & 15.4947 & 0.0345 \\
\hline At most 1 & 0.0253 & 0.9257 & 3.8414 & 0.336 \\
\hline \multicolumn{5}{|c|}{ Unrestricted Co-integration Rank Test (Maximum Eigenvalue) } \\
\hline Hypothesized No. of CE(s) & Eigenvalue & Trace Statistic & 0.05 Critical Value & Prob. \\
\hline None & 0.3522 & 15.6333 & 14.2646 & 0.0302 \\
\hline At most 1 & 0.0253 & 0.9257 & 3.8414 & 0.336 \\
\hline
\end{tabular}

Source: Author`s own calculation

Based on the Johansen co-integration test results we rejected the null hypothesis of both trace and maximum eigenvalue tests of no co-integration between GDP and FDI at $1 \%$ level of significance, but we failed to reject the alternative hypothesis $(P$-value in both tests $>0.05 \%$, and Trace/Maximum Eigenvalue $<0.05$ Critical Value $=3.8414$ ) (See Table 2). Thus, we can confirm the existence of at most one long-run co-integration vector between GDP and FDI.

\subsubsection{Granger Causality test}

As we have already mentioned, we checked the causal relationship between GDP and FDI through Granger Causality test. The null hypothesis of the test states the following: 
$H_{0}:$ LnFDI does not Granger Cause LnGDP, and

$H_{0}$ : LnGDP does not Granger Cause LnFDI

Null hypothesis is rejected if the probability value is less than $0.05 \%$.

Table 3. Granger causality test results

\begin{tabular}{lll}
\hline Pairwise Granger causality test, Lags 2, Sample 1980-2017 & \\
\hline Null Hypothesis & F-statistic & Prob. \\
LnFDI does not Granger Cause LnGDP & 4.696 & 0.016 \\
LnGDP does not Granger Cause LnFDI & 2.251 & 0.122
\end{tabular}

Source: Author's own calculation

According to the results we can reject the null hypothesis of no causal relationship from FDI to GDP (Pvalue $=0.016<0.05 \%)$, and except the second null hypothesis $(P$-value $=0.122>0.05)$. Thus, the results of causality test indicated the unidirectional causal relationship from FDI to GDP (See Table 3).

\section{Conclusion}

This study analyzes the relationship between Foreign Direct Investment inflows to Economic Growth of Turkey by using annual data for the period span from 1980 to 2017. Unit root test (ADF), Johansen co-integration test and Granger Causality test were applied for empirical part of paper to examine the impact of Foreign Direct Investment inflows on Economic growth(GDP) of Turkey.

The findings showed us further; According to the results of Unit root test both of variables were stationary. That meant we could continue our calculations by applying Johansen co-integration and Granger Causality tests. The next step was Johansen co-integration test. Johansen co-integration test confirms the existence of at most one long-run co-integration vector between GDP and FDI. The final step to complete our empirical analysis part of paper was Granger Causality test. Based on results there was unidirectional causal relationship from FDI to GDP.

\section{References}

[1] Alagöz, M., Erdoğan, S., \& Topallı, N. (2008). Doğrudan Yabancı Sermaye Yatırımları ve Ekonomik Büyüme: Türkiye Deneyimi 1992-2007, 11.

[2] Çeştepe, H., Yildirim, E., \& Bayar, M. (n.d.). DOĞRUDAN YABANCI YATIRIM, EKONOMIK BÜYÜME VE DIŞ TICARET: TODA-YAMAMOTO YAKLAŞIMIYLA TÜRKIYE'DEN NEDENSELLIK KANITLARI, 37.

[3] Deichmann, J., Karidis, S., \& Sayek, S. (2003). Foreign direct investment in Turkey: regional determinants. Applied Economics, 35(16), 1767-1778. https://doi.org/10.1080/0003684032000126780

[4] Gürsoy, F., \& Kalyoncu, H. (2012). Foreign Direct Investment and Growth Relationship in Georgia. International Journal of Economics and Financial Issues, 2.

[5] Muhammad, L., \& ljirshar, V. U. (2015). Empirical Analysis of the Relationship between Foreign Direct Investment and Economic Growth in Developing Countries-Evidence from Nigeria. International Journal of Business Administration and Management Research, 1(1), 15-25.

[6] Şen, A., \& Saray, M. O. (2010). TÜRKIYE'DE DOĞRUDAN YABANCI SERMAYE YATIRIMLARININ EKONOMIK BÜYÜMEYE ETKISI: PANEL VERI ANALIZi. Akademik Araştırmalar ve Çalışmalar Dergisi (AKAD), 0(0). https://doi.org/10.20990/aacd.07150

[7] World Bank Group - International Development, Poverty, \& Sustainability. (n.d.). Retrieved November 2, 2018, from http://www.worldbank.org/ 
[8] Yilmaz, Ö., Kaya, V., \& Akinci, M. (2011). TÜRKIYE'DE DOĞRUDAN YABANCI YATIRIMLAR VE EKONOMIK BÜYÜMEYE ETKISI (1980-2008). Atatürk Üniversitesi İktisadi ve İdari Bilimler Dergisi, 25(3-4), 13-30.

[9] Younus, H. S., Sohail, A., \& Azeem, M. (2014). Impact of foreign direct investment on economic growth in Pakistan. World Journal of Financial Economics, 1(1), 2-5 